\title{
Cohort Profile of The GOALS Study: A Large-scale Research of Physical Activity in Dutch Students
}

Citation for published version (APA):

De Groot, R., Van Dijk, M., \& Kirschner, P. A. (2015). Cohort Profile of The GOALS Study: A Large-scale Research of Physical Activity in Dutch Students. British Journal of Educational Psychology, 46(5), 947-952. https://doi.org/10.1111/bjet.12284

DOI:

10.1111/bjet.12284

Document status and date:

Published: 13/08/2015

Document Version:

Early version, also known as pre-print

Document license:

CC BY-SA

Please check the document version of this publication:

- A submitted manuscript is the version of the article upon submission and before peer-review. There can be important differences between the submitted version and the official published version of record. People interested in the research are advised to contact the author for the final version of the publication, or visit the DOI to the publisher's website.

- The final author version and the galley proof are versions of the publication after peer review.

- The final published version features the final layout of the paper including the volume, issue and page numbers.

Link to publication

\section{General rights}

Copyright and moral rights for the publications made accessible in the public portal are retained by the authors and/or other copyright owners and it is a condition of accessing publications that users recognise and abide by the legal requirements associated with these rights.

- Users may download and print one copy of any publication from the public portal for the purpose of private study or research.

- You may not further distribute the material or use it for any profit-making activity or commercial gain

- You may freely distribute the URL identifying the publication in the public portal.

If the publication is distributed under the terms of Article 25fa of the Dutch Copyright Act, indicated by the "Taverne" license above, please follow below link for the End User Agreement:

https://www.ou.nl/taverne-agreement

Take down policy

If you believe that this document breaches copyright please contact us at:

pure-support@ou.nl

providing details and we will investigate your claim.

Downloaded from https://research.ou.nl/ on date: 26 Apr. 2023 


\section{Cohort Profile of The GOALS Study: A Large-scale Research of Physical Activity in Dutch Students}

Renate H.M. de Groot ${ }^{1}$, PhD, Martin L. van Dijk ${ }^{1}$, Msc, Paul. A. Kirschner ${ }^{1}$, PhD.

${ }^{1}$ Welten Institute, Faculty of Psychology and Educational Sciences, Open University of the Netherlands, Valkenburgerweg 177, 6419 AT Heerlen, the Netherlands

* Correspondence: RenatedeGroot@ou.nl 


\section{ABSTRACT}

The GOALS study (Grootschalig Onderzoek naar Activiteiten van Limburgse Scholieren [Large-scale Research of Activities in Dutch Students]) was set up to investigate possible associations between different forms of physical activity and inactivity with cognitive performance, academic achievement and mental wellbeing. It was conducted at a secondary school in the south of the Netherlands. Data collection took place during normal school weeks from October 2011 to March 2012 and one year later from October 2012 to May 2013. The study was approved by the local Ethical Committee of the Open University of the Netherlands.

All students in grades 7 and 9 of senior general secondary education and university preparatory education were invited to participate $(\mathrm{N}=526)$. At baseline a sample of 440 Dutch-speaking adolescents was willing to participate (83.7\%). Of these, 344 participated in the follow-up.

Physical activity was measured objectively by an ActivPal3 ${ }^{\mathrm{TM}}$ accelerometer. Cognitive performance was measured by the D2 test of attention and the Symbol Digit Modalities Test. Academic achievement was determined using the mean of school grades in Dutch, English, and Mathematics. Several well-validated instruments were used to determine mood/depressive symptoms, self-esteem and goal orientation. Information on several covariates such as sex, academic year, school level, ethnicity, socioeconomic status, BMI, pubertal status, smoking, drinking, viewing television, computer use etc. are available. 


\section{THE DATASET}

\section{Location and DOI}

At the moment, the data is stored on a local server. In the future the data will be transferred to DANS Data Archiving and Networked Services -

(http://www.dans.knaw.nl/en).

\section{Creator}

Renate H.M. de Groot, Paul A. Kirschner and Martin L. van Dijk.

\section{Date}

Baseline data was collected between October 2011 and March 2012, follow up data between October 2012 and May 2013.

\section{Format}

Different formats are possible (e.g., SPSS, Excel, R data).

\section{Restrictions to use (if any)}

As the research papers based on The GOALS Study are still in progress, data will be revealed only after the determination of whether an inquiry will not compete with our own research questions. For further information or admission to the data, contact us via the contact information given in the author note. We declare the intention to publish the data in DANS by the end of 2015. 


\section{INTRODUCTION}

The relationship between physical activity level and cognitive performance (see Ploughman, 2008) or academic achievement (see Trudeau \& Shephard, 2008) has become a field of interest for many. An increasing amount of research suggests a positive association between physical activity and brain functioning (see Hillman, Erickson, \& Kramer, 2008). Similarly, a negative association between physical inactivity (ref) and brain functioning is also becoming more evident (ref). The ratio between this activity and inactivity seems to play a role in brain functioning as well (ref).

However, most research in this field has focused on children (Trudeau \& Shephard, 2008) or older adults (Colcombe \& Kramer, 2003), while adolescents - as a group have not received much attention. This group is of special interest as brain-imaging research has shown that frontal brain areas continue to develop throughout childhood and adolescence, becoming fully matured only after the age of twenty (Gogtay et al., 2004; Paus, 2005; Toga, Thompson, \& Sowell, 2006). Research in older adults has shown that physical activity yielded the largest benefit on executive-control processes (Colcombe \& Kramer). The prefrontal cortex, the area still developing during adolescence is the most important brain domain involved in these executive functions. Investigation of the association between physical activity and cognitive and academic performance during adolescence is therefore of great value.

Previous studies, which investigated this link, predominantly measured physical activity subjectively through questionnaires (ref). It could be argued that the results from these studies might be biased due to social desirability, recall bias (Slootmaker, Schuit, Chinapaw, Seidell, \& van Mechelen, 2009) and over- or underestimation of time spent in physical activity (Chinapaw, Slootmaker, Schuit, van Zuidam, \& van 
Mechelen, 2009; Bassett, Cureton, \& Ainsworth, 2000). The GOALS Study

(Grootschalig Onderzoek naar Activiteiten van Limburgse Scholieren [Large-scale

Research of Activities in Dutch Students]) is one of the first studies in which physical activity/inactivity is measured objectively in adolescents and linked to cognitive performance, academic achievement and mental well-being. In addition, it is the first study in which physical activity/inactivity as well as cognitive performance and academic achievement are measured objectively in a longitudinal design.

\section{RESEARCH METHOD}

\section{Design, procedure, participants}

The GOALS Study has a longitudinal observational design. All students from grades 7 and 9 of senior general secondary education or university preparatory education from a high school in the south of the Netherlands were invited to participate in the study $(\mathrm{N}=526)$. In the classroom, information was distributed to the students as well as an invitation for an information evening for their parents/guardians. In total, 440 students agreed to participate (response rate $=83.7 \%$ ).

At baseline (October 2011 through March 2012) waterproofed ActivPAL3 ${ }^{\mathrm{TM}}$ accelerometers, which had to be worn for one full week, 24 hours/day were taped to the midpoint of the anterior part of the thigh to measure physical activity. A shuttlerun test was executed, data with respect to weight and height were collected and several questionnaires regarding mood, self-esteem and goal orientation were filled in.

Exactly one week later the accelerometers were removed and the participants performed several cognitive tests in classical setting. At the end of the academic year, the school provided school grades and absenteeism information. 
A one-year follow-up took place by repeating the above-mentioned procedures in the same participants one year later (October 2012 till May 2013).

\section{Independent measurements}

\section{Objectively measured physical (in)activity}

The ActivPAL3 ${ }^{\text {TM }}$ accelerometer (Paltechnologies, Glasgow, UK) was used to measure physical activity/inactivity during a normal school week. This small device $(53 \times 35 \times 7 \mathrm{~mm})$ measures bodily accelerations and identifies the wearer's posture. Data were recorded at $20 \mathrm{~Hz}$ and summarised in 15-second time intervals (epochs). Data output for each epoch included number of steps, energy expenditure (i.e., metabolic equivalent/h), and time spent sitting/lying, standing, and moving.

\section{Self-reported physical activity}

The IPAQ-A (International Physical Activity Questionnaire in Adolescents) was used to subjectively assess the physical activity behaviour of the study population (ref).

\section{Computer gaming}

Gaming habits were measured with a newly developed questionnaire based on Meijs, Hurks, Feron, and Jolles (2007). Participants were asked about their gaming habits and their favorite gaming categories (i.e., sports, strategic, fighting, puzzle, adventure, learning games).

\section{Television viewing}

Television viewing was measured with two questions based on research by Hancox, Milne, and Poulton (2005). Participants were asked 'On school days, how many hours 
a day do you watch television'? and 'On weekend days, how many hours a day do you watch television?'. Participants were categorised into one of four groups: viewing $\leq 1$ hour, between $1-\leq 2$ hours, between $2 \leq 3$ hours and $>3$ hours on average a day (Hancox et al.).

\section{Dependent variables}

\section{Cognitive performance}

The Symbol Digit Modalities Test was used to measure basic information processing speed (ref).

The d2 Test of Attention was used to measure selective attention and response inhibition ref.

\section{Academic achievement}

End of year school grades (ranging from 1.0 $=$ fail to $10=$ outstanding) were acquired from the school's administration. Academic achievement is determined by the arithmetic mean of three subjects, namely Dutch, mathematics and English as a foreign language. These are the first three main goals of secondary education in the Netherlands (Ministry of Education, Culture and Science, 2006), and are valid estimators of academic achievement (Reed, Ouwehand, Van der Elst, Boschloo, \& Jolles, 2010).

\section{Mood / depressive symptoms}

The Centre for Epidemiologic Studies Depression Scale Revised CESD-R (Radloff, 1977) was used to measure depressive symptoms in the general population.

Respondents rated the frequency - over the previous week - of twenty symptoms 
ranging from rarely or none of the time (0) to most or all of the time (3). A total score was calculated as the sum of all items, and ranged from 0 (not depressed) to 60 (high amount of depressive symptoms).

\section{Self-esteem}

The Rosenberg self-esteem scale (1965) was used to measure self-esteem. It consists of ten statements dealing with general feelings about the respondent's own personality. Participants had to indicate on a 4-point Likert scale, whether they strongly agree (1), agree (2), disagree (3) or strongly disagree (4) with the statements.

\section{Covariates}

Sex, body mass index (BMI), alcohol consumption, smoking behavior and socioeconomic status

- BMI was calculated as body weight in kilograms divided by height in meters squared.

- Alcohol consumption was measured via a short self-report questionnaire and will be dichotomised into 'high' ( $>2$ drinks containing alcohol $>2$ evenings per week) or 'low/none' intake categories. This is based on the Dutch Trimbos-institute (2010) advice for adolescents until the age of 16 years..

- Smoking status was assessed with a single question ('current smoker' yes/no).

- Socioeconomic status was determined by Level of Parental Education (LPE). Parents were asked to report both parents' educational level. LPE is defined as the highest education of the two. Educational level is scored on an 8 point scale ranging from primary education to higher vocational education and university (De Bie, 1987). 


\section{Pubertal phase}

Pubertal phase was measured through Petersen, Crockett, Richards, and Boxer's (1988) self-administered Pubertal Developmental Scale.

\section{Aerobic fitness}

The 20-m shuttle-test (20-MST) was used to measure aerobic fitness, as described by Leger, Mercier, Gadoury, and Lambert (1988).

\section{ETHICAL CONSIDERATIONS}

The local Ethical Committee of the Open University of the Netherlands (reference number: U2013/ 07405/HVM) approved the study. A comprehensive description of the nature and purpose of the study was given to parents/guardians, school supervisors and adolescents. Parents and/or guardians signed an objection form in case they did not agree with participation of their children or in case the students themselves did not agree to take part in the study.

\section{LIMITATIONS}

Our data are collected at one secondary school in the Netherlands. Results can thus not been generalized to the whole Dutch adolescent population. However this choice was made on purpose to increase homogeneity of the variables regarding academic achievement. Namely, often schools differ in grading and teaching policies. These problems were tackled by including only one large secondary school. Like in all studies and inherent to scientifically designed studies, selection bias might be present in our study; It can be expected that girls or obese adolescents were possibly less 
inclined to participate in the study compared to boys or slender adolescents, respectively. However in The GOALS Study an equal number of boys and girls participated in the study and the mean BMI was in accordance with the overall Dutch adolescent population (Snoek, van Strien, Janssens, \& Engels, 2007), suggesting that this selection bias was not a serious issue in this population.

\section{ACKNOWLEDGEMENTS}

This research was supported by the NIHC (Nationaal Initiatief Hersenen \& Cognitie

[National Initiative Brain \& Cognition]) funded by FES (Fonds Economische

Structuurversterking [Fund Economic Structure Reinforcement]).

\section{REFERENCES}

